\title{
Direct Undersowing of Degraded Stands with Annual and Perennial Legumes in the Northern Bulgaria
}

\author{
Galina Naydenova ${ }^{1} \cdot V_{i l i a n a}$ Vasileva $^{2}$
}

1Experimental Station of Soybean, blv. "Ruski" 61, 5200 Pavlikeny, Bulgaria

Institute of Forage Crops, Gen. Vladimir Vazov 89, 5800 Pleven, Bulgaria

\begin{abstract}
Summary: The possibility of annual and perennial legume crops to be used for undersowing of degraded pasture stands and alfalfa seed production stands was studied in the conditions of the Northern Bulgaria. The direct undersowing of degraded pasture stands was done after harvest with these legumes: birdsfoot trefoil (Lotus corniculatus L.), red clover (Trifolium pratense L.), black medick (Medicago lupulina L.), arrowleaf clover (Trifolium vesiculosum Savi), and common vetch (Vicia sativa L.). The undersowing of degraded seed production stands of alfalfa was done in autumn of the fourth year of using with subterranean clover (Tr. subterraneum ssp. brachycalicinum $\mathrm{cv}$. Antas). Red clover showed the best results in terms of suitability for the direct undersowing of degraded pasture stands. Subterranean clover could be used for the direct undersowing of the degraded alfalfa seed production stands due to its self-seeding ability.

Key words: direct undersowing, degradation, legumes, alfalfa, pastures, arrowleaf clover, subterranean clover
\end{abstract}

\section{Introduction}

The permanent changes having occurred in the last ten-year period in the climate (increase of average annual temperatures, long droughts in spring and summer, increase of $\mathrm{CO}_{2}$ concentration in the atmosphere) present a serious risk to the agricultural crops (Mannetje, 2006; Gornall et al., 2010; Aranjueloa et al., 2014). They have a negative impact on the species composition, productivity and quality of dry matter, as well as their durability. Climate change requires adaptation of forage crops and mixtures to the changed conditions and greater efficiency of resource use (Lelièvre \& Volaire, 2009).

Direct undersowing is used to recover and/or prolong the persistence of the degraded pastures and meadows. It is applied in degraded stands, where the legume components are dropped due to the short duration, less adaptability to over use, adverse soil and climatic conditions, or other factors. By including legumes crops through this method, it is expected that it prolongs the durability of the stands, enhance the productivity and quality of the forage (Springer, 1997).

When selecting the legume for the direct undersowing, it is necessary to provide for its adaptability to the habitat, for which it is intended, the sowing rate as well as the regime of use of the stands (Abusuwar et al., 1993; Riday, 2008). For areas with a

Corresponding author: viliana.vasileva@gmail.com temperate climate mostly used legume crops for this purpose are clovers (Trifolium spp.), birdsfoot trefoil (Lotus spp.) and alfalfa (Medicago spp.) (Entz et al., 2007; Escaray et al., 2012).

Arrowleaf clover is an annual legume crops with winter type of development. It is characterized by high productivity and excellent quality of the forage (Ovalle et al., 2010; Naydenova et al., 2014). This legume is used successfully for undersowing of couch grass pastures in the United States (Han et al., 2012; Freeman et al., 2014).

Red clover (Trifolium pratense L.) is defined as a legume with the greatest potential to meet the objectives of the direct undersowing, due to the rapid initial growth of seedlings in the conditions of competition, tolerance of shade and good compatibility with the most common types of forage grasses (Riday, 2008; Mihovski, 2009; Naydenova et al., 2013).

Black medick (Medicago lupulina L.) is water-saving and easily-maintained turf legume with high protein and low fibre content and it is suitable for grazing (Cao et al., 2003).

At present, crops that can provide self-sowing and persist continuously in the stands become of practical importance (Carneiro, 1999; Nichols et al., 2012; Bartholomew, 2014). Such is subterranean clover (Trifolium subterraneum L.) - an annual drought resistant ephemeral legume with winter-spring type of development (Yakimova \& Yancheva, 1986; Piano et al., 1996). As a nitrogen-fixing crop it is a widespread component in the pastures and other grasslands of the 
temperate areas of Central and Northern Europe and America (Pecetti \& Piano, 1998, 2002; Nichols et al., 2013). Studies with this crops over the past years show that it has a practical application for the climatic conditions of Bulgaria (Vasilev, 2006; Vasilev \& Vasilev, 2012a; Vasilev \& Vasilev, 2012b; Vasileva et al., 2011, 2015; Vasileva, 2015; Ilieva et al., 2015). The effective utilization of autumn-winter soil moisture, successful seed formation and self-sowing at the end of spring allow to the subterranean clover to avoid summer droughts (Piano et al., 1996; Porqueddu et al., 2003).

The objective of this work was to assess the results of direct undersowing of degraded pasture stands and degraded alfalfa seed production stands with annual and perennial legume crops in the conditions of Northern Bulgaria.

\section{Materials and Methods}

Experimental work was carried out on two locations in Bulgaria as follows:

1. Direct undersowing of degraded pasture stands with adapted genotypes (varieties and local populations) annual and perennial legumes. Experimental work was carried out through undersowing of pasture stands, categorized as municipal land, used for unregulated grazing in the area of town of Pavlikeni $\left(43^{\circ} 24^{\prime} \mathrm{N}, 53^{\circ} 32^{\prime} \mathrm{E}, 144 \mathrm{~m}\right)$, Bulgaria. The field trial was laid down in the autumn of 2013 with an area of the experimental plot of size of 5 $\mathrm{m}^{2}$, four replicated. Direct undersowing was done with the following types of legumes: birdsfoot trefoil (Lotus corniculatus L.), a local pasture ecotype; red clover (Trifolium pratense L.), cv. Nika 11; black medick (Medicago lupulina L.), local population (from the area of the town of Pavlikeni); arrowleaf clover (Trifolium vesiculosum Savi) wild population (from the area of Strandja) and common vetch (Vicia sativa L.), the selection line.

The sowing rate for birdsfoot trefoil, red clover, black medick, and arrowleaf clover was 2000 germinated seeds per $\mathrm{m}^{2}$, and 400 germinated seeds per $\mathrm{m}^{2}$ for common vetch. The sowing was done in the middle of October 2013 after the harvesting of the pasture stands. Plant samples of $0.25 \mathrm{~m}^{2}$ were taken from the each replication and determined as follows: in the first year after undersowing (2014) - relative ratio of the legumes (\%) (weight) (used for undersowing) during the spring growth (May) and autumn regrowth (October); during the second year after undersowing (2015) - relative ratio of legumes (\%) during the spring growth (May), regrowth of the second cut (June) and autumn regrowth (October). The plant height of the legumes was measured $(\mathrm{cm})$ during the spring growth (for red clover - during the formation of the first cut (May); for arrowleaf clover - at the beginning of July 2015 during the flowering).

2. Direct undersowing of degraded seed production stands of alfalfa with subterranean clover. Experimental work was carried out on the experimental field of the Institute on Forage Crops, Pleven $\left(43^{\circ} 23^{\prime} \mathrm{N}, 24^{\circ} 37^{\prime} \mathrm{E}, 109 \mathrm{~m}\right)$, Bulgaria, on soil subtype leached chernozem. The long plots method was used, the size of the plot of $5 \mathrm{~m}^{2}$ and 4 replications. Alfalfa seed production stands (cv. Pleven 6) was sown in 2007 and carried during the vegetation according to the common technology. In the autumn of the fourth year (2010) of exploitation, cross the lines undersowing was done with subterranean clover. Tr. subterraneum ssp. brachycalicinum (cv. Antas) was used and undersowing was done with 400 number of germinated seeds $\mathrm{m}^{-2}$. Four cuts were obtained during the first and second year after undersowing (2011 and 2012), and three cuts during the last year (2013). Before the each cutting plant samples were taken from $0.25 \mathrm{~m}^{2}$ and the relative ratio of the subterranean clover $(\%)$ was determined, as well the plant height $(\mathrm{cm})$ was measured. The experimental data were processed statistically using SPSS software (2012).

\section{Results and Discussion}

1. Direct undersowing of degraded pasture stands with adapted genotypes (varieties and local populations) annual and perennial legumes. Growing season of 2014 was characterized by very wet conditions during summer months. The amount of rainfall was $578 \mathrm{l} / \mathrm{m}^{2}$ vs. $367 \mathrm{l} /$ $\mathrm{m}^{2}$ in 50 year period (Table 1). In 2015, temperatures and rainfall did not deviate from the climatic norm for the area, with the exception of July, when high drought was observed.

The best results in the year after undersowing (2014) are obtained from the red clover and black medick (Figure 1). The highest relative ratio of common vetch was observed during the month of May (24.1\%). No seedlings were recorded during the spring of the first experimental year for birdsfoot trefoil and arrowleaf clover. The ratio of red clover was above $90 \%$ and the ratio of the black medic above $50 \%$ in the end of vegetation.

Large ratio of red clover compared to other legumes in terms of direct undersowing was related to the biology characteristics of this species, namely the rapid growth of seedlings as well as tolerance to shading (Sheaffer et al., 2003; Riday et al., 2008). Gorski et al. (1984) and Oleszek et al. (1992) found allelopathic activity of black medick. According to the authors, black medick contains up to $2.5 \%$ of the dry matter hemolytic saponins, which exhibit allelopathic action against the grasses, suppressing germination and growth. We assume that this is the reason for the good results obtained from the undersowing in 2014.

In the second year after undersowing due to differences in the development of clovers, arrowleaf clover had small ratio in the stands in May, when the first cut of perennial grasses was formed. Arrowleaf clover presence was approximately $50 \%$ in June, when the second cut of red clover was formed (Table 2). 
Table 1. Agrometeorological conditions for the period of 2013-2015

\begin{tabular}{|c|c|c|c|c|c|c|}
\hline \multirow[t]{2}{*}{ Months/years } & \multicolumn{2}{|c|}{2013} & \multicolumn{2}{|c|}{2014} & \multicolumn{2}{|c|}{2015} \\
\hline & $\mathrm{t}$ & rainfall & $\mathrm{t}$ & rainfall & $\mathrm{t}$ & rainfall \\
\hline & ${ }^{\circ} \mathrm{C}$ & $1 / \mathrm{m}^{2}$ & ${ }^{\circ} \mathrm{C}$ & $1 / \mathrm{m}^{2}$ & ${ }^{\circ} \mathrm{C}$ & $1 / \mathrm{m}^{2}$ \\
\hline January & 0.5 & 34.0 & 1.5 & 38.0 & 2.1 & 27.0 \\
\hline February & 4.6 & 45.0 & 3.5 & 4.0 & 2.7 & 39.0 \\
\hline March & 6.9 & 39.0 & 10.0 & 89.0 & 7.3 & 76.0 \\
\hline April & 14.5 & 66.0 & 13.2 & 68.0 & 12.4 & 40.0 \\
\hline May & 22.0 & 43.0 & 17.8 & 93.0 & 19.8 & 66.0 \\
\hline June & 21.8 & 112.0 & 21.6 & 91.0 & 21.0 & 86.0 \\
\hline July & 23.2 & 78.0 & 23.4 & 106.0 & 25.6 & 20.0 \\
\hline August & 24.7 & 16.0 & 24.3 & 12.0 & 24.8 & 72.0 \\
\hline September & 19.4 & 14.0 & 18.3 & 115.0 & 19.9 & 47.0 \\
\hline October & 13.5 & 94.0 & 12.4 & 94.0 & 11.6 & 38.0 \\
\hline November & 9.4 & 34.0 & 6.0 & 54.0 & 9.7 & 51.9 \\
\hline December & 0.6 & 3.0 & 2.6 & 85.0 & & \\
\hline $\mathrm{Av} / \mathrm{sum}$ & 13.4 & 578.0 & 12.9 & 849.0 & 14.3 & 562.9 \\
\hline
\end{tabular}

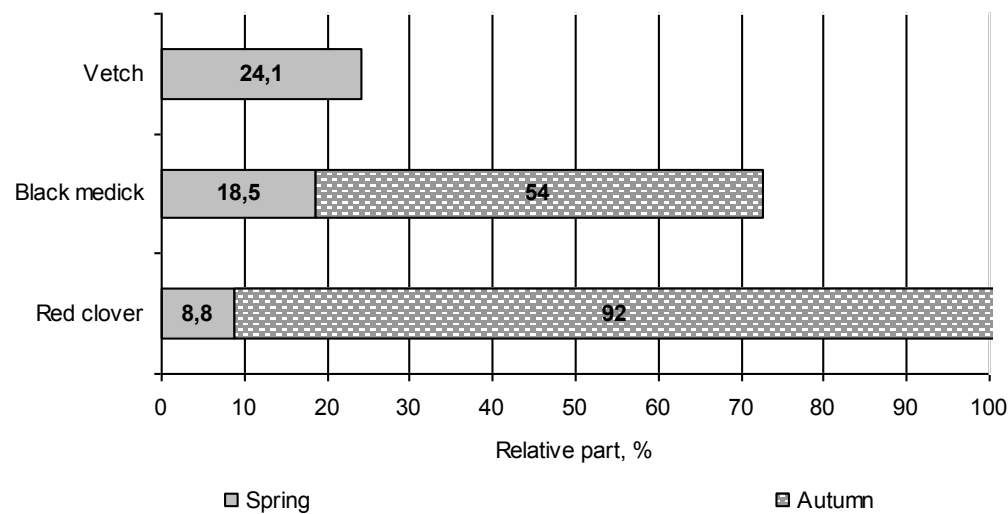

Figure 1. Relative ratio of legumes in the stands during the year after undersowing (2014)

Due to late sowing and winter type of development, arrowleaf clover appeared in the stands in the second growing season (2015) after the second wintering, which is an indicator of good storage of seeds in the soil seed bank. In the conditions of the Central Northern Bulgaria the seeds of arrowleaf clover showed good environmental adaptation. This biological characteristic could be used in practice.

For areas with Mediterranean climate, the selection of arrowleaf clover for hardiness of the seeds is leading, which allows its gradual emergence and thus selfsupporting in the stands for several years, although it is an annual type (Loi et al., 2005). Subterranean clover has similar behaviour. Naydenova et al. (2014) found that this genotype of arrowleaf clover sown before
September 10 germinates in autumn, overwinters successfully, has slowly spring development, but until July 10 to 15 develops dense stands, $50-60 \mathrm{~cm}$ tall, with a strong branched generative stems.

It is believed that the development of sown seeds of plants has been slow due to the existing competition. Considering the characteristic height/ length of the generative stems for red clover and arrowleaf clover, it is seen that these crops were considerably lower in comparison with the same when the stands were created by a standard method (Table 3 ). In contrast, black medick and common vetch (this breeding line), which is of wintering type, did not react to the undersowing by reducing the length of the generative stems. 
Table 2. Relative ratio of legumes in the stands during the second year after undersowing (2015)

\begin{tabular}{lccc}
\hline \multirow{2}{*}{ Undersown species } & Spring growth & Second cut & Autumn regrowth \\
\cline { 2 - 4 } & May & June & October \\
\hline Birdsfoot trefoil & 0.0 & 0.0 & 0.0 \\
Red clover & 81.4 & 88.6 & 71.3 \\
Black medick & 0.0 & 0.0 & 0.0 \\
Arrowleaf clover & 27.6 & 48.5 & 0.0 \\
Vetch & 0.0 & 0.0 & 0.0 \\
\hline
\end{tabular}

Table 3. Height of the plants during the spring growth (first cut) and pure stands created by standard technology (Naydenova et al., 2012; 2014)

\begin{tabular}{lccc}
\hline \multirow{2}{*}{ Under sowed species } & \multicolumn{2}{c}{ Height, cm } \\
\cline { 2 - 4 } & 2014 & direct undersowing & standard technology \\
\hline Red clover & $28.85 \pm 1.20$ & 2015 & 70.2 \\
Black medick & $31.35 \pm 1.74$ & $34.45 \pm 3.39$ & 30.6 \\
Arrowleaf clover & 0.0 & 0.0 & 53.3 \\
Vetch & $55.60 \pm 1.90$ & $24.70 \pm 1.38$ & 54.5 \\
\hline
\end{tabular}

To succeed in a type after undersowing, the sowing rate should be above a certain threshold, which is specific to the species as well to its habitat. Therefore it would be good if different sowing rates were studied. We assume that the sowing rate should be increased in vetch and birdsfoot trefoil. It does not neglect the fact that the used genotypes are most adapted to the conditions of the experiment, as they were selected exactly for those of Central North Bulgaria.

2. Direct undersowing of degraded seed production stands of alfalfa with subterranean clover. Agrometeorological conditions during the period of the experiment could be determined as unfavourable (Table 4). In the year after undersowing long dry period with extremely high temperatures was occurred. Unevenly distributed rainfall and long (duration 82 days) drought in summer are characteristics of the second experimental year.

Despite the unfavourable conditions experienced throughout the period, subterranean clover self-seeded successfully and its participation in the cuts is presented in Figure 2. In the first year after undersowing the ratio of subterranean clover in the first cut reached $22 \%$. In the next cuts it was present but insignificant - there were self-seeded plants, but the their height was up to $5.3 \mathrm{~cm}$ (data not shown).

The participation of subterranean clover in the second year reached $10 \%$ in the first and second cuts. During the formation of third and fourth cuts of alfalfa, the agrometeorological conditions were extremely unfavourable for the development of all crops, due to the prolonged drought.

During the third year after undersowing from the three obtained cuts, subterranean clover participated in the stands of the first and second cuts. Its ratio was $6.8 \%$ in the first and $5.2 \%$ in the second cut.

The most developed plants were in the first cut, when they used autumn-winter moisture for germination (Table 5). During the third experimental year after undersowing, the plant height in the first cut varied from $13.7 \mathrm{~cm}$ to $17.5 \mathrm{~cm}$.

In the second cut better developed plants were those from the second and third year after undersowing. This is related to the biology of the crops, as well as the agrometeorological conditions. Precipitation in late summer facilitated emergence of new self-seeded plants. 
Table 4. Agrometeorological conditions for the period of 2011-2013

\begin{tabular}{|c|c|c|c|c|c|c|}
\hline \multirow[t]{2}{*}{ Months/years } & \multicolumn{2}{|c|}{2011} & \multicolumn{2}{|c|}{2012} & \multicolumn{2}{|c|}{2013} \\
\hline & $\mathrm{t}$ & rainfall & $\mathrm{t}$ & rainfall & $\mathrm{t}$ & rainfall \\
\hline & ${ }^{\circ} \mathrm{C}$ & $1 / \mathrm{m}^{2}$ & ${ }^{\circ} \mathrm{C}$ & $1 / \mathrm{m}^{2}$ & ${ }^{\circ} \mathrm{C}$ & $1 / \mathrm{m}^{2}$ \\
\hline January & -1.0 & 32.8 & -0.1 & 44.2 & 0.5 & 19.0 \\
\hline February & 0.2 & 27.2 & -5.2 & 17.8 & 3.9 & 60.9 \\
\hline March & 6.1 & 25.7 & 8.5 & 7.6 & 6.3 & 39.6 \\
\hline April & 11.4 & 28.2 & 14.8 & 46.3 & 14.0 & 50.8 \\
\hline May & 16.8 & 79.8 & 17.4 & 85.2 & 19.5 & 63.7 \\
\hline June & 21.4 & 33.6 & 24.1 & 40.3 & 21.3 & 112.4 \\
\hline July & 23.5 & 50.2 & 27.8 & 1.4 & 22.7 & 105.8 \\
\hline August & 23.6 & 41.3 & 25.8 & 35.6 & 24.9 & 20.2 \\
\hline September & 22.0 & 0.0 & 21.1 & 21.0 & 18.4 & 15.8 \\
\hline October & 11.1 & 50.2 & 15.0 & 56.0 & 12.2 & 59.2 \\
\hline November & 7.6 & 0.4 & 8.1 & 4.0 & 8.7 & 29.1 \\
\hline December & 3.9 & 28.6 & -1.0 & 56.7 & 0.2 & 2.3 \\
\hline Av/sum & 12.2 & 398.0 & 13.0 & 416.1 & 12.7 & 578.8 \\
\hline
\end{tabular}

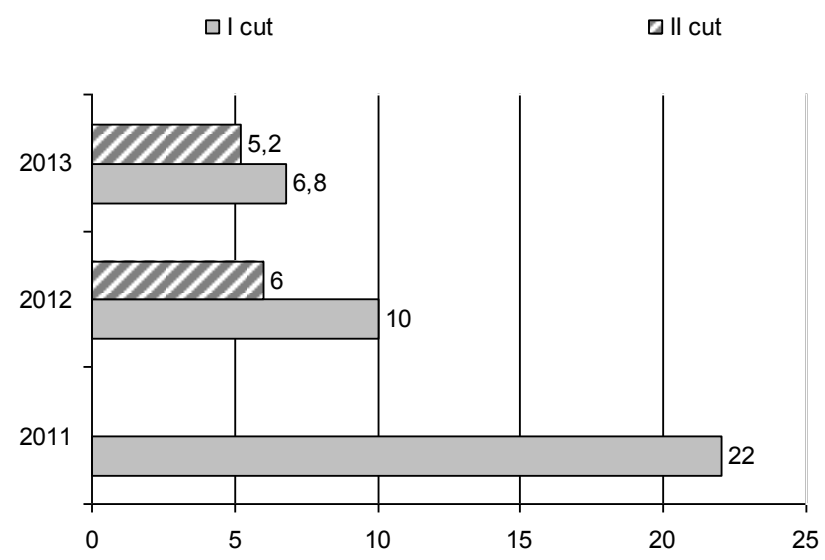

Figure 2. Relative ratio (\%) of subterranean clover in under sowed degraded seed production stands of alfalfa

Table 5. Height of self-seeded subterranean clover plants $(\mathrm{cm})$ in degraded seed production stands of alfalfa

\begin{tabular}{lccc}
\hline Cuts & & Plant height, cm & \\
\cline { 2 - 4 } & 2011 & 2012 & $13.7 \pm 2.31$ \\
\hline I & $17.5 \pm 0.4$ & $16.6 \pm 0.61$ & $10.7 \pm 0.58$ \\
II & $5.3 \pm 1.1$ & $10.7 \pm 0.58$ & 0.0 \\
III & $4.0 \pm 1.6$ & 0.0 & \\
IV & $3.7 \pm 1.5$ & 0.0 & 0 \\
\hline
\end{tabular}

\pm , STDEV 


\section{Conclusions}

Red clover showed the best results regarding the suitability of the adapted genotypes (varieties and local populations) of annual and perennial legumes for direct undersowing of degraded pasture stands. Black medick and arrowleaf clover have potential importance as crops for undersowing, but the concretization of the technology is needed to ensure their presence in the stands for the years of period.

Subterranean clover can be used for direct undersowing of degraded seed production alfalfa stands. It is an annual leguminous species, but because of the biological ability for self-seeding, with the presence at the beginning and end of growing season, it behaves as a perennial type with extended durability of the stands.

\section{References}

Abusuwar, A., Dixon, R. M., \& Schonhorst, M. H. (1993). Imprintation Inter-Seeding, Soil Moisture and Seedling Emergence. University of Khartoum, Journal of Agriculture Sciences, 1, 59-80.

Aranjueloa, I., Arrese-Igor, C., \& Moleroc, G. (2014). Nodule performance within a changing environmental context. Journal of Plant Physiology, 171, 1076-1090.

Bartholomew, P. W. (2014). Self-Seeding Warm-Season Legumes for LowInput Forage Production in the Southern Great Plains of the USA. Agricultural Sciences, 5, 1112-1118.

Cao, Zh. Zh., Feng, Y. Q., Ma, H. L., Liu, X. N., Zhou, Y. L., \& ZM, X. U. (2003). Medicago lupulina - beautiful water-saving and easily-maintained turf legume. Pratacultural Science, 4, 58-60.

Carneiro, J. P. (1999). Avaliação de luzernas anuais em solos á cidos, Estudo do efeito de alguns factores com vista ao melhoramento deplantas. Doutoramento em Engenharia Agronomica. Univercidade Técnica de Lisboa.

Entz, M. H., Thiessen Martens, J. R., May, W., \& Lafond, G. P. (2007). Black medic (Medicago lupulina) germplasm screening for use as a selfregenerating cover crop on the Canadian Prairies. Can. J. Plant Sci., 87, 873-878.

Escaray, F., Menendez, A., Garriz, A., Pieckenstain, F., Estrella, M., Castagno, L., Carrasco, P., Sanjuan, J., \& Ruiz, O. (2012). Ecological and agronomic importance of the plant genus Lotus. Its application in grassland sustainability and the amelioration of constrained and contaminated soils. Plant Science, 182, 121-133.

Freeman, S. R., Poore, M. H., Glennon, H. M., \& Shaeffer A. D. (2014). Winter Annual Legumes Overseeded into Seeded Bermudagrass (Cynodon dactylon): Productivity, Forage Composition, and Reseeding Capability. Forage and Grazinglands, 12, 1. http://dx.doi.org/10.2134/ FG-2013-0060-RS

Gornall, J., Betts, R. Burke, E., Clark, R., Camp, L., Willett, K., \& Wiltshire, A. (2010). Implications of climate change for agricultural productivity in the early twenty-first century. Philosophical Transactions of the Royal Society, B 365, 2973-2989.

Gorski, P. M., Turzysta, M., Burda, S., Oleszek, W., \& Ploszinsky, M. (1984). Studies on Medicago lupilina saponins IV. Variation in saponin content of $M$ lupilina. Acta Societatis Botanicorum Poloniae, 53(4), 543-550.

Han, K. J., Alison, M. W., Pitman, W. D., \&. McCormick, M. E. (2012). Contribution of overseeded clovers to bermudagrass pastures in several environments. Crop Science, 52, 431-441.

Ilieva, A., Vasileva, V., \& Katova, A. (2015). The effect of mixed planting of birdsfoot trefoil, sainfoin, subterranean clover, and tall fescue on nodulation and nitrate reductase activity in shoots. Journal of Global Agriculture and Ecology, 3(4), 222-228.

Lelièvre, F., \& Volaire, F. (2009). Current and Potential Development of Perennial Grasses in Rainfed Mediterranean Farming Systems. Crop Science, 49, 2371-2378.

Loi, A., Howieson, J. G., Nutt, B. J., \& Carr, S. J. (2005). A second generation of annual pasture legumes and their potential for inclusion in Mediterranean-type farming systems. Aust. J. Exp. Agric., 45, 289299.

Mannetje, L.'t. (2006). Climate change and grassland through the ages- an overveiw. In: Lloveras, J., Gonzales-Rodríguez, A., Vazquez-Yañez, O., Piñeiro, J., Santamaría, O., Olea, L. \& Poblaciones, M. J. (Eds.), Sustainable Grassland Productivity. Proceedings of the 21st General Meeting of the European Grassland Federation, Badajoz, 3-6 April, 2006. Grassland Science in Europe, 11, 733-738.

Mihovski, Ts. (2009). Preliminary results of evaluation of Bulgarian germplasm of red clover (Trifolium pratense L.). Genetics and Breeding, 38 (3-4), 195-199.

Naydenova, G., Ilieva, A., \& Aleksieva, A. (2012). Investigation of winter vetch accessions as initial material for breeding in grass-feed direction. Journal of Mountain Agriculture on the Balkans, 15, 1388-1404.

Naydenova, G., Mihovski, Ts., \& Balabanova, D. (2013). Red clover cv. "Nika 11". Animal Science, 7, 33-34. (In Bulgarian)

Naydenova, G., Naydenova, Y., Mihovski, Ts., \& Iliev, M. (2014). Forage potential of annual legume crops in Bulgaria. Agricultural Science, 47(23), 48-54.

Nichols, P. G. H., Foster, K. J., Piano, E., Pecetti, L., Kaur, P., Ghamkhar, K., \& Collins, W. J. (2013). Genetic improvement of subterranean clover (Trifolium subterraneum L.). 1. Germplasm, traits and future prospects. Crop and Pasture Science, 64, 312-346.

Nichols, P. G. H., Revell, C. K., Humphries, A. W., Howie, J. H., Hall, E. J., Sandral, G. A., Ghamkhar, K., \& Harris, C. A. (2012). Temperate pasture legumes in Australia - their history, current use and future prospects. Crop and Pasture Science, 63, 691-725.

Oleszek, W., Jurzysta, M., \& Górski, P. M. (1992). Alfalfa saponins - the allelopathic agents. Allelopathy. Basic and Applied Aspects, 151-167.

Ovalle, C., Pozo, A., Fernández, F., Chavarría, J., \& Arredondo, S. (2010). Arrowleaf clover (Trifolium vesiculosum Savi): a new species of annual legumes for high rainfall areas of the mediterranean climate zone of chile. Chilean Journal of Agricultural Research, 70(1), 170-177.

Pecetti, L., \& Piano, E. (1998). Leaf size variation in subterranean clover (Trifolium subterraneum L. sensu lato). Genetic Resources and Crop Evolution, 45(2), 161-165.

Pecetti, L., \& Piano, E. (2002). Variation of morphological and adaptive traits in subterranean clover populations from Sardinia (Italy). Genetic Resources and Crop Evolution, 49(2), 189-197.

Piano, E., Pecetti, L., \& Carroni, A. M. (1996). Climatic adaptation in subterranean clover populations. Euphytica, 92, 39-44.

Porqueddu, C., Parente, G., \& Elsaesser, M. (2003). Potential of grasslands. In: A. Kirilov, N. Todorov \& I. Katerov (Eds.). Grassland Science in Europe, 8, 11-20.

Riday, H. (2008). Heritability of frost-seeded red clover establishment. Euphytica, 163: 81-87.

Sheaffer, C., Ehlke, N., Albrecht, K., \& Peterson, P. (2003). Forage legumes. 2nd ed. Minn Agric Exp Station Bulletin, 608.

Springer, T. L. (1997). Effect of bermudagrass height on clover establishment. Crop Sci., 37, 1663-1665.

Vasilev, E. (2006). Productivity of subterranean clover (Tr. subterraneum L.) in pasture mixtures with some perennial grasses for the conditions of Central North Bulgaria. Plant Science, S., 43(2), 149-152. (In Bulgarian)

Vasileva, V. (2015). Morphological parameters and ratios in some mixtures with subclover. Science International, 3(4), 107-112.

Vasileva, V., Kocheva, K., Mincheva, J., Georgiev, G., Ilieva, A., \& Porqueddu, C. (2016). Physiological analysis of growth and nitrogen metabolism of intercropped pasture species subterranean clover (Trifolium subterraneum L.) and cocksfoot (Dactylis glomerata L.) supplemented with different inorganic nitrogen. Journal of Plant Nutrition, 40

Vasileva, V. \& Vasilev, E. (2012a). Study on Productivity of some Legume Crops in Pure Cultivation and Mixtures. Agriculturae Conspectus Scientificus, 77(2), 91-94.

Vasileva, V., \& Vasilev E. (2012b). Dry mass yield from some pasture mixtures with subterranean clover (Trifolium subterraneum L.). Journal of Mountain Agriculture on the Balkeans, 15, 1024-1033.

Vasileva, V., Vasilev, E., \& Athar, M. (2011). Nodulation and root establishment of two clover species grown in pasture mixtures with wheatgrass. FUUAST Journal of Biology, 1(1), 1-4.

Yakimova, Y., \& Yancheva, H. (1986). Phytocenological and ecological characteristics of some annual clovers in Strandja region, Plant Science, 23(4), 47-53. (In Bulgarian). 


\section{Direktno podsejavanje degradiranih parcela \\ jednogodišnjim i višegodišnjim mahunarkama u severnoj Bugarskoj}

\section{Galina Naydenova · Viliana Vasileva}

Sažetak: U uslovima severne Bugarske ispitivana je mogućnost korišćenja jednogodišnjih i višegodišnjih mahunarki za podsejavanje degradiranih pašnjaka i lucerišta za semensku proizvodnju. Degradirani pašnjaci su direktno podsejani nakon žetve sledećim mahunarkama: žuti zvezdan (Lotus corniculatus L.), crvena detelina (Trifolium pratense L.), obična vija (Medicago lupulina L.), gušava detelina (Trifolium vesiculosum Savi) i obična grahorica (Vicia sativa L.). Degradirana lucerišta za semensku proizvodnju su podsejana podzemnom detelinom (Tr. subterraneum ssp. brachycalicinum cv. Antas) u jesen četvrte godine korišćenja. Crvena detelina je pokazala najbolje rezultate što se tiče pogodnosti za direktno podsejavanje degradiranih pašnjaka. Podzemna detelina bi se mogla koristiti za direktno podsejavanje degradiranih lucerišta za semensku proizvodnju zbog sposobnosti da sama zaseje svoje seme.

Ključne reči: degradacija, direktno podsejavanje, gušava detelina, lucerka, mahunarke, pašnjak, podzemna detelina 